\title{
Biodiesel Co-products Modified the Rumen Parameters of Feedlot Lambs but did Not Change Methane Production In Vitro*
}

\author{
Eliéder Prates Romanzini', Américo Garcia da Silva Sobrinho' ${ }^{1}$, Roberta de Lima Valença², \\ Thiago Henrique Borghi', Fernanda de Almeida Merlim', Nomaíaci de Andrade', \\ Nivea Maria Brancacci Lopes Zeola', Pablo de Souza Castagnino' \& Priscila Arrigucci Bernardes ${ }^{3}$
}

\begin{abstract}
Background: Intensification of livestock is a strategy that increases productivity, but the diets used to increase animal production efficiency are composed mainly of corn and soybean, thereby increasing competition between animals and humans for the same food crops. This study evaluated nutrient intake, apparent digestibility of dry matter (DM) and nutrients, kinetics of gas production, and concentration of volatile fatty acids on diets with or without inclusion of biodiesel co-products formulated for feedlot lambs. So, the hypothesis is that replace of traditional ingredients by biodiesel co-products changes rumen parameters and methane emissions.

Materials, Methods \& Results: The experiment was developed in São Paulo State University (Unesp), Jaboticabal, SP, Brazil, in Sheep Production Laboratory, which is owned to Animal Science Department. All trials developed in this study used a feedlot system, where animals were kept in individual pen. Forty Ile de France lambs male non-castrated were used in in vivo trial. To obtain rumen fluid, that was used in in vitro trial, four Santa Inês lambs with rumen cannula were used. The treatments evaluated were four diets: Control diet: roughage + concentrate; PM20: roughage + concentrate with peanut meal (PM) at $20 \%$ of DM; CG25: roughage + concentrate with crude glycerin (CG) at $25 \%$ of DM; and PMCG: roughage + concentrate with PM at 10\% of DM and CG at 12.5\% of DM. The roughage:concentrate ratio was 40:60 for all these diets. The parameters of the in vitro and in vivo experiments used were completely randomized with four treatments. When significant, the means between treatments were compared using Tukey test $(P<0.05)$. There was no effect of coproduct inclusion on intake, except ether extract and neutral detergent fiber, which were higher for PM20 compared with CG25 diet. Apparent digestibility of dry matter (79.87\%) and some nutrients (organic matter, crude protein, and neutral detergent fiber) was higher $(P<0.05)$ with CG25 diet. In vitro cumulative gas production was greater in CG25 and PMCG compared to the other diets, at early measurement points $(2,4,6$, and $10 \mathrm{~h})$. The concentrations of methane, volatile fatty acids, and acetate:propionate ratio in vitro did not differ $(P>0.05)$ among diets.

Discussion: Probably the high quality of the glycerin used (83.9\% glycerol, $12.01 \%$ humidity, $3.79 \%$ salts, and $0.28 \%$ organic matter, no fat, as described by the manufacturer) may explain the low EE concentration observed in the diet using only crude glycerin and the observed lack of DMI effects in all diets. About apparent digestibility, the greater values measured for crude protein can be explained by superior synchronism during fermentation of the proteins and carbohydrates in the diet. The data showed that treatment CG25 obtained higher initial gas production, followed by treatment PMCG which contained $12.5 \%$ crude glycerin. Probably these results were caused by the greater apparent digestibility of DM in treatments that included crude glycerin. Our results of volatile fatty acid concentration are different from the decrease in molar proportion of acetic acid and increase of propionic acid described by several authors, with the inclusion of glycerin in the diet. However, the absence of effect by co-product inclusion on the molar proportion of acetic, propionic, and butyric acids measured in this trial reinforce the report from other authors that affirmed the same situation. Hence, the inclusion of $\mathrm{PM}$ at $20 \%$ of DM and CG at $25 \%$ of DM could successfully replace the traditional diets of feedlot lambs such as soybean and corn, respectively, without damages to intake and ruminal parameters in vitro.
\end{abstract}

Keywords: apparent digestibility, lamb, nutrient intake, volatile fatty acid. ${ }^{1}$ Department of Animal Science, School of Agricultural and Veterinarian Sciences, São Paulo State University (Unesp), Jaboticabal, SP, Brazil. ${ }^{2}$ Federal Rural University of Pernambuco (UFRPE). Academic Unit Garanhuns (UAG), Garanhuns, PE, Brazil. ${ }^{3}$ Santa Catarina Federal University (UFSC). Department of Animal Science and Rural Development, Florianópolis, SC, Brazil. CORRESPONDENCE: E.P. Romanzini [elieder.romanzini@ gmail. com]. Department of Animal Science, Unesp. Via de Acesso Paulo Donato Castellane s/n. CEP 14.884-900 Jaboticabal, SP, Brazil. 


\section{INTRODUCTION}

Reduce competition between human and animal nutrition has been a quest of some researchers around the world. In this way, attractive protein and energy sources to replace the traditional feeds include biodiesel co-products, such as peanut meal (PM) and crude glycerin $(\mathrm{CG})$, the latter rapidly becoming a problem as its excess from bio-fuel production accumulates in the environment [10].

Several studies have replaced protein content of animal feeds with peanut meal in feedlot systems resulting both adequate performance and apparent digestibility of dry matter and nutrients [9,24,25]. Similarly, crude glycerin has been used as an energy ingredient $[4,8]$; besides other studies that described the effects of crude glycerin in terms of gas production kinetics [6,28]. However, the effects of replacing both energy and protein from corn and soybeans with crude glycerin and peanut meal on animal digestion parameters and kinetics of gas production remain unknown.

Therefore, our hypothesis is that replace of traditional ingredients by biodiesel co-products changes rumen parameters and methane emissions. We aimed to determine whether a diet including biofuel co-products could successfully replace the traditional animal feeds. For this, we evaluated the effect of replacing the soybean meal and corn in diets used for feedlot lambs with the biodiesel co-products peanut meal and crude glycerin on nutrient intake, apparent digestibility of dry matter and nutrients, as well as on the concentration of methane and volatile fatty acids.

\section{MATERIALS AND METHODS}

The experiment was developed in São Paulo State University (Unesp), Jaboticabal/SP, Brazil. Inside Sheep Production Laboratory $\left(21^{\circ} 15^{\prime} 22^{\prime}\right.$ 'South, 48 18 '58" West and 595 masl), which is owned to Animal Science Department. The weather conditions on place is characterized by wet summer and dry winter, typical for subtropical humid. The trial, both phases in vivo and in vitro, was developed using as structure a feedlot system with individual pen, where animals were kept until slaughtered, specifically for animals used for in vivo trial.

\section{Experimental diets and chemical analyses}

The experimental diets used in the in vivo and in vitro trials (Table 1) were formulated for weaned lambs, with average weight gain of $300 \mathrm{~g} / \mathrm{d}$ [21].The roughage to concentrate ratio was 40:60 in all diets, with treatments consisting of Control (roughage + concentrate), PM20 (roughage + concentrate with PM at $20 \%$ of DM), CG25 (roughage + concentrate with $\mathrm{CG}$ at $25 \%$ of DM), and PMCG (roughage + concentrate with PM at $10 \%$ of DM and $\mathrm{CG}$ at $12.5 \%$ of DM). The diets had near quantities of nitrogen $(17.00 \% \mathrm{CP})$ and metabolizable energy (2.70 Mcal.kg DM ${ }^{-1}$ ) among the different treatments.

The samples of diets and feed refusals obtained from the digestibility trial were oven-dried at $55^{\circ} \mathrm{C}$ for $72 \mathrm{~h}$ and ground through a Willey mill with a $1 \mathrm{~mm}$ sieve. After this, they were stored and analyzed to determine dry matter (DM, 934.01), mineral matter (MM, 942.05), and ether extract (EE, 920.39) according to AOAC (2006). Nitrogen concentration was determined using an LECO FP1 - 528 nitrogen analyzer. The metabolizable energy was calculated after determination of crude energy in adiabatic bomb calorimeter ${ }^{2}[21,26]$.

Neutral detergent fiber (NDF) was determined using $\alpha$-amylase and without the addition of sodium sulfite, adapted for Ankom200 Fiber Analyzer ${ }^{3}$ [30]. The acid detergent fiber was determined using the method described by Goering and Van Soest [12], adapted for Ankom200 Fiber Analyzer ${ }^{3}$.

\section{Apparent digestibility and nutrient intake trial}

We used 40 Ile de France lambs, male non-castrated, weighing $21.02 \pm 2.14 \mathrm{~kg}$, housed in metabolic pens with individual feeders and drinkers. The feed was provided twice per day ( 7 and $17 \mathrm{~h}$ ), allowing $10 \%$ feed refusals. The daily feed intake was calculated as the difference between daily feed offered and refused from each animal.

The animals were maintained in adaptation to the diets for fifteen days and the metabolic pens for seven days. Five days were then used to collect all the feces, as well as dietary samples. The feces were collected in plastic bowls and $10 \%$ of total was sampled and stored at $-18^{\circ} \mathrm{C}$. At the end of the digestibility trial, a composite sample was created for each animal. For determine intake daily and apparent digestibility of DM and nutrients, the feces were analyzed to determine $\mathrm{DM}, \mathrm{OM}, \mathrm{CP}, \mathrm{EE}$, and NDF $[3,12,30]$.

In vitro gas production and volatile fatty acid quantification

Santa Inês lambs $(n=4 ; 31.2 \pm 0.75 \mathrm{~kg} \mathrm{BW})$ were housed in individual pens with an area of $2 \mathrm{~m}^{2}$, equipped with individual feeders and water drinkers, and contained in a covered shed. Each animal received 
an experimental diet during 10 days' adaptation period. The diet was offered ad libitum in two daily meals (8 and $17 \mathrm{~h}$ ), allowing $10 \%$ feed refusals.

The kinetics of gas production [27] adapted to the semi-automatic system [15] was used. The mixed rumen fluid of cannulated Santa Inês lambs fed each diet was used as inoculum for incubation. The rumen fluid collection was conducted at 6:00 h, strained through a triple layer of gauze under continuous $\mathrm{CO}_{2}$ injection, and mixed with the buffer solution [27]. The ratio of buffer:ruminal fluid was 8:2 [12].

Buffered ruminal solution $(30 \mathrm{~mL})$ was transferred to 20 flasks (115 mL), each containing approximately $200 \mathrm{mg}$ of one of the diets (total diet compounded by mix previously describe (Table 1), previously weighed. The flasks were sealed and incubated anaerobically in a water bath at $39^{\circ} \mathrm{C}$. The pressure caused in the flasks was measured at 2, 4, 6, 10, 12, 24, 26, 28, $30,32,36$ and $48 \mathrm{~h}$ after incubation using a pressure transducer and data logger (PDL200) ${ }^{4}$. The pressure values were converted to volume of gas using the equation previously determined for laboratory conditions: $Y$ = 7.3669X - 0.2336; where: $\mathrm{Y}=$ gas volume $(\mathrm{mL}) ; \mathrm{X}=$ measured pressure (psi). Flasks (blanks) without diets tested were used in duplicate to adjust for gas production of nutrients present in the buffered rumen fluid.

At $48 \mathrm{~h}$ post incubation $5 \mathrm{~mL}$ of gases were collected in syringes and immediately injected into the chromatograph (Shimadzu CG-2014, Greenhouse gas analyzer $)^{5}$, which was using packed column Hayesep D 80/100 mesh, 4 m, 1/8 with flame ionization detector (FID) for methane quantification. After this, the flasks were removed from the incubator, opened, and the $\mathrm{pH}$ of culture fluid was measured, using digital $\mathrm{pH}$ meter (Marconi model MA-522) ${ }^{6}$. The flasks were immersed in ice water to inhibit microbial activity and immediately sampled for subsequent analysis. Aliquots of 10 $\mathrm{mL}$ were collected for determination of volatile fatty acids and subsequently stored at $-20^{\circ} \mathrm{C}$. The volatile fatty acids were measured in a gas chromatograph ${ }^{5}$ with an HP-INNOWax capillary column ${ }^{7}$ (30 m x 0.32 $\mathrm{mm} ; 0.50 \mu \mathrm{m}$ film thickness) at an initial temperature of $80^{\circ} \mathrm{C}$ and a final temperature of $240^{\circ} \mathrm{C}$.

\section{Statistical analysis}

The parameters of the in vitro and in vivo experiments used were completely randomized with four treatments (3 degrees of Freedom, DF). When significant, the means between treatments were compared using Tukey test with 5\% significance. The General Linear Model (GLM) procedure of the SAS software SAS 9.1 was used. In vitro cumulative gas production in function of measurement times realized in the in vitro trial was evaluated by analysis of repeated measures based on the incubation times using the Mixed Linear models (PROC MIXED) procedure of the SAS software SAS $9.1^{8}$.

Table 1. Composition and nutritive value of the experimental diets.

\begin{tabular}{|c|c|c|c|c|}
\hline Diet & Control & PM20 & CG25 & PMGB \\
\hline \multicolumn{5}{|c|}{ Composition (\%) } \\
\hline Corn silage & 40.00 & 40.00 & 40.00 & 40.00 \\
\hline Crude glycerin & - & - & 25.00 & 12.50 \\
\hline Peanut meal & - & 20.00 & - & 10.00 \\
\hline Soybean meal & 21.00 & - & 32.35 & 16.00 \\
\hline Corn grain & 36.25 & 37.00 & - & 18.66 \\
\hline Dicalcium phosphate & 1.45 & 1.90 & 1.50 & 1.70 \\
\hline Limestone & 0.30 & 0.10 & 0.15 & 0.14 \\
\hline Premix & 1.00 & 1.00 & 1.00 & 1.00 \\
\hline \multicolumn{5}{|c|}{ Chemical analyses (g.kg DM $\left.{ }^{-1}\right)$} \\
\hline Dry matter (DM) & 654.1 & 662.1 & 653.7 & 657.9 \\
\hline Organic matter $(\mathrm{OM})$ & 935.8 & 938.6 & 922.9 & 930.7 \\
\hline Crude protein $(\mathrm{CP})$ & 173.7 & 177.8 & 172.6 & 174.6 \\
\hline Ether extract (EE) & 40.2 & 39.4 & 17.7 & 28.6 \\
\hline Mineral matter (MM) & 64.2 & 61.4 & 77.1 & 69.3 \\
\hline Neutral detergent fiber (NDF) & 263.9 & 302.0 & 213.7 & 257.9 \\
\hline Acid detergent fiber (ADF) & 148.7 & 165.3 & 130.5 & 147.8 \\
\hline \multicolumn{5}{|c|}{ Nutritional value } \\
\hline Metabolizable energy $\left(\text { Mcal. kg DM }{ }^{-1}\right)^{1}$ & 2.80 & 2.74 & 2.64 & 2.68 \\
\hline
\end{tabular}




\section{RESULTS}

There was no difference (Table 2) in DM, OM, $\mathrm{CP}$, and ADF intake with inclusion of dietary biodiesel co-products (peanut meal and crude glycerin) $(P>0.09)$. However, the apparent digestibility was greater in the CG25 diets compared with DM, OM, and NDF diets.

The EE and NDF intake were different between treatments $(P<0.05)$. The lowest EE intake were observed for lambs fed with CG25and PMCG, which have low levels of this nutrient in their chemical composition (17.7 and $28.6 \mathrm{~g} / \mathrm{kg}$ in DM, Table 1).

The DM and OM intakes were not affected by the inclusion of peanut meal and crude glycerin $(P>$ 0.41). The daily NDF intake was different between animals fed with PM20 and CG25 diets $(P<0.05)$, mainly due to diet composition wherein PM20 diet contained about 9\% more NDF than CG25 diet.

The evaluated diets showed significant differences in the apparent digestibility of DM and nutrients
$(P<0.05)$. The DM apparent digestibility was greater in CG25 and PMCG, followed by PM20 and Control diets (Table 2; $P<0.001$ ).

In vitro cumulative gas production was greater in the CG25, and another one was similar diets (Table 3; $P<0.001)$ at the first three time points studied $(2,4$ and $6 \mathrm{~h})$. At the next time point $(10 \mathrm{~h})$ only CG25 differed $(P>0.05)$ from Control diet. The CG25 diet showed the most gas production among the diets, with 10.68 , 18.69, 23.37, and $28.71 \mathrm{~mL} / \mathrm{g}$ DM for the times 2, 4, 6 and $10 \mathrm{~h}$, respectively. After first four time points, the in vitro cumulative gas production was similar between the diets $(P>0.09)$.

Final $\mathrm{pH}$ and methane concentration in vitro did not change $(P=0.87)$ among diets (Table 4$)$. The concentrations of volatile fatty acids measured and the acetate:propionate ratio in the diets were not affected by the replacement of the traditional ingredients with the biodiesel co-products $(P>0.31)$.

Table 2. Daily nutrient intake and apparent digestibility of dry matter and nutrients in Ile de France feedlot lambs fed with or without diets containing biodiesel co-products.

\begin{tabular}{|c|c|c|c|c|c|c|}
\hline \multirow{2}{*}{ Variable } & \multicolumn{4}{|c|}{ Experimental diets } & \multirow{2}{*}{ S.E.M. } & \multirow{2}{*}{$P$-value } \\
\hline & Control & PM20 & CG25 & PMCG & & \\
\hline \multicolumn{7}{|c|}{ Intake (kg.day $\left.{ }^{-1}\right)$} \\
\hline DM & 0.809 & 0.901 & 0.812 & 0.806 & 0.02 & 0.44 \\
\hline OM & 0.741 & 0.822 & 0.751 & 0.733 & 0.02 & 0.41 \\
\hline $\mathrm{CP}$ & 0.119 & 0.136 & 0.123 & 0.150 & 0.01 & 0.43 \\
\hline $\mathrm{EE}$ & $0.035^{\mathrm{a}}$ & $0.031^{\mathrm{a}}$ & $0.015^{\mathrm{b}}$ & $0.023^{\mathrm{b}}$ & $<0.01$ & $* * *$ \\
\hline NDF & $0.256^{\mathrm{ab}}$ & $0.310^{\mathrm{a}}$ & $0.248^{\mathrm{b}}$ & $0.284^{\mathrm{ab}}$ & 0.01 & $*$ \\
\hline $\mathrm{ADF}$ & 0.131 & 0.161 & 0.136 & 0.139 & $<0.01$ & 0.09 \\
\hline \multicolumn{7}{|c|}{ Apparent digestibility (\%) } \\
\hline DM & $69.26^{\mathrm{c}}$ & $71.04^{c}$ & $79.87^{\mathrm{a}}$ & $76.01^{\mathrm{b}}$ & 1.19 & $* * *$ \\
\hline OM & $70.37^{b}$ & $72.71^{\mathrm{b}}$ & $81.26^{\mathrm{a}}$ & $77.76^{\mathrm{a}}$ & 1.23 & $* * *$ \\
\hline $\mathrm{CP}$ & $54.57^{\mathrm{b}}$ & $69.29^{\mathrm{a}}$ & $70.04^{\mathrm{a}}$ & $71.85^{\mathrm{a}}$ & 2.28 & $* *$ \\
\hline $\mathrm{EE}$ & $88.21^{\mathrm{a}}$ & $89.91^{\mathrm{a}}$ & $80.82^{\mathrm{b}}$ & $87.52^{\mathrm{a}}$ & 1.10 & $* *$ \\
\hline NDF & $49.29^{\mathrm{b}}$ & $57.23^{\mathrm{ab}}$ & $64.23^{\mathrm{a}}$ & $63.92^{\mathrm{a}}$ & 2.05 & $*$ \\
\hline
\end{tabular}

S.E.M.: square error mean. DM: dry matter; OM: organic matter; CP: crude protein; EE: ether extract; NDF: neutral detergent fiber; ADF: acid detergent fiber. Control: roughage + concentrate; PM20: roughage + concentrate with 20\% peanut meal on DM; CG25: roughage + concentrate with $25 \%$ crude glycerin on DM; PMCG: roughage+ concentrate with $10 \%$ peanut meal and $12.5 \%$ crude glycerin on DM. ${ }^{a, b}$ Means in the same row with different letters are significantly different at $P<0.05$. $* P<0.05 * * P<0.01 * * * P<0.001$.

\section{DISCUSSION}

\section{Nutrient intake and apparent digestibility}

Lambs with more than $20 \mathrm{~kg}$ of BW must intake $1.20 \mathrm{~kg}$ of DM daily to gain an average of 300 $\mathrm{g}$ of weight daily [21]. In this study, this recommendation was not fulfilled, however considering the DMI to body weight ratio $(3.85,4.29,3.86$, and $3.83 \% \mathrm{BW}$ for Control, PM20, CG25, and PMCG, respectively) it can be observed that the animals consumed considerable quantities.

Even with low DMI, the average daily CPI $(0.132 \mathrm{~kg})$ obtained from all treatments was similar to recommendation $(0.124 \mathrm{~kg})$ for lambs. This may occur due to absence of difference in DMI added to fact that diets have equal nitrogen levels (Table 1). 
Table 3. In vitro cumulative gas production (mL.g DM ${ }^{-1}$ ) after $48 \mathrm{~h}$ of incubation of diets containing or not containing biodiesel co-products.

\begin{tabular}{|c|c|c|c|c|c|c|}
\hline \multirow{2}{*}{ Variable } & \multicolumn{4}{|c|}{ Experimental diets } & \multirow{2}{*}{ S.E.M. } & \multirow{2}{*}{$P$ - value } \\
\hline & Control & PM20 & CG25 & PMCG & & \\
\hline \multicolumn{7}{|c|}{ Time $(\mathrm{h})$} \\
\hline 2 & $4.96^{c}$ & $5.64^{\mathrm{c}}$ & $10.68^{a}$ & $7.03^{b}$ & 0.29 & $* * *$ \\
\hline 4 & $13.05^{\mathrm{b}}$ & $14.18^{b}$ & $18.69^{\mathrm{a}}$ & $14.67^{\mathrm{b}}$ & 0.60 & $* * *$ \\
\hline 6 & $18.80^{\mathrm{b}}$ & $19.81^{b}$ & $23.37^{\mathrm{a}}$ & $20.19^{b}$ & 0.65 & $* * *$ \\
\hline 10 & $25.63^{\mathrm{b}}$ & $26.96^{\mathrm{ab}}$ & $28.71^{\mathrm{a}}$ & $26.86^{\mathrm{ab}}$ & 0.75 & $*$ \\
\hline 12 & 29.92 & 30.75 & 31.52 & 30.37 & 0.94 & 0.66 \\
\hline 24 & 42.26 & 42.16 & 40.18 & 41.89 & 1.06 & 0.47 \\
\hline 26 & 44.23 & 43.90 & 41.70 & 43.75 & 1.07 & 0.34 \\
\hline 28 & 45.21 & 44.78 & 42.51 & 44.69 & 1.16 & 0.35 \\
\hline 30 & 45.99 & 45.48 & 43.26 & 45.82 & 1.18 & 0.33 \\
\hline 32 & 47.71 & 46.93 & 44.98 & 47.69 & 1.24 & 0.37 \\
\hline 36 & 48.24 & 47.36 & 45.44 & 48.45 & 1.19 & 0.28 \\
\hline 48 & 51.72 & 50.50 & 48.95 & 52.31 & 0.99 & 0.09 \\
\hline
\end{tabular}

S.E.M.: square error mean. Control: roughage + concentrate; PM20: roughage + concentrate with 20\% peanut meal on DM; CG25: roughage + concentrate with $25 \%$ crude glycerin on DM; PMCG: roughage+ concentrate with $10 \%$ peanut meal and $12.5 \%$ crude glycerin on DM. ${ }^{\mathrm{a}, \mathrm{b}} \mathrm{Means}$ in the same row with different letters are significantly different at $P<0.05$. $* P<0.05 * * P<0.01 * * * P<0.001$.

Table 4. $\mathrm{pH}$, methane concentration, volatile fatty acid concentration and acetate:propionate ratio in diets with or without inclusion biodiesel co-products.

\begin{tabular}{|c|c|c|c|c|c|c|}
\hline \multirow{2}{*}{ Variable } & \multicolumn{4}{|c|}{ Experimental diet } & \multirow{2}{*}{ S.E.M. } & \multirow{2}{*}{$P$ - value } \\
\hline & Control & PM & $\mathrm{CG}$ & PMCG & & \\
\hline $\mathrm{pH}$ & 6.98 & 7.00 & 6.94 & 6.93 & 0.03 & 0.87 \\
\hline $\mathrm{CH}_{4}\left(\% . \mathrm{g} \mathrm{DM}_{\text {incubated }}{ }^{-1}\right)$ & 9.95 & 9.76 & 9.93 & 10.27 & 0.27 & 0.93 \\
\hline \multicolumn{7}{|c|}{ Volatile fatty acids (mMol) } \\
\hline Acetate & 54.60 & 56.05 & 50.06 & 54.33 & 0.97 & 0.36 \\
\hline Propionate & 23.87 & 25.42 & 31.04 & 27.37 & 1.23 & 0.37 \\
\hline Butyrate & 15.43 & 15.89 & 11.90 & 14.14 & 0.78 & 0.31 \\
\hline Valerate & 2.23 & 2.34 & 2.26 & 2.30 & 0.03 & 0.71 \\
\hline Isobutyrate & 2.08 & 2.18 & 1.87 & 1.98 & 0.09 & 0.72 \\
\hline Isovalerate & 3.68 & 3.92 & 3.57 & 3.69 & 0.16 & 0.93 \\
\hline Acetate:Propionate & 2.30 & 2.23 & 1.61 & 2.00 & 0.12 & 0.35 \\
\hline
\end{tabular}

$\mathrm{CH}_{4}$ : methane concentration was measured $48 \mathrm{~h}$ after incubation for in vitro gas production. S.E.M.: square error mean. Control: roughage + concentrate; PM20: roughage + concentrate with $20 \%$ peanut meal on DM; CG25: roughage + concentrate with $25 \%$ crude glycerin on DM; PMCG: roughage+ concentrate with $10 \%$ peanut meal and $12.5 \%$ crude glycerin on DM.

Probably the high quality of the glycerin used (83.9\% glycerol, $12.01 \%$ humidity, $3.79 \%$ salts, and $0.28 \%$ organic matter, no fat, as described by the manufacturer) may explain the low EE concentration observed in the diet using only crude glycerin and the observed lack of DMI effects in all diets. Evaluating crude glycerin levels $(0,3,6,9,12 \% \mathrm{DM})$ in feedlot lambs, a research concluded that failures in the process of separating glycerin from the fuel promoted high levels of fat acids in this co-product [13].

Similar results were reported by Correia et al. [9], who evaluated intake of nutrients using diets composed of the biodiesel co-products palm kernel, peanut, and sunflower meals in crossbred cattle cannulated in the rumen. These authors observed that DM and EE intakes did not differ between animals fed with peanut meal and Control diets.

When NDF intake (NDFI) is greater than $1.2 \%$ $\mathrm{BW}$, there will be control in food consumption by ruminal repletion [17]. This study presented an NDFI average of $1.37 \% \mathrm{BW}$, which is greater than $1.2 \% \mathrm{BW}$. Therefore, the daily NDFI interfered in DMI, which was similar between diets (Table 2).

The inclusion of crude glycerin $(0,10$, and $20 \%$ $\mathrm{DM}$ ) in diets of feedlot lambs resulted an absence of difference in daily NDFI between the experimental diets [16]. The average NDFI obtained reported by this author for diets tested was $0.227 \mathrm{~kg}$. This value was near to average of the CG25 $(0.248 \mathrm{~kg})$ and PMCG $(0.284 \mathrm{~kg})$ diets used herein. 
Similar to the results obtained with the Control and PM20 diets tested in this study, Mota et al [19] evaluated the daily NDFI (\% BW) found no difference between diets with peanut meal and soybean meal inclusion. They concluded that the daily NDFI (\% BW) did not differ between the diets using peanut meal and soybean meal because the diet compositions were similar in terms of NDF. This occurred in this study, where the Control and PM20 diets had similar NDF levels when compared to the diet with crude glycerin inclusion, the CG25 diet. Digestibility is determined by the diet and by intrinsic animal characteristics, such as the enzymatic and microbial systems. Considering this condition, the crude glycerin has digestibility similar to ground corn grain [18].

Replacement of soybean meal with peanut cake $(0,33.33,66.67$ and $100 \% \mathrm{DM})$ in diets with equal protein levels (16\%) resulted values of DM digestibility for goats of $70.10 \%$ on average [25]; quite similar to those described in this study for lambs. However, in contrast to those authors, we found significant differences for this variable between diets with peanut meal inclusion in comparison with diets with crude glycerin inclusion. This was probably due the chemical composition of diets, in that there was lower NDF in diets including crude glycerin compared to diets including peanut meal.

Due high purity of crude glycerin used in this study, there was an increase in DM apparent digestibility. In this way, when assessing co-product inclusion $(2.65,5.33,8.06$, and $10.84 \%)$ with low purity $(43.9 \%$ glycerol on natural matter), found a linear and negative effect with increase of crude glycerin inclusion, with an average value for apparent digestibility of DM (60\%) lower than the $79.87 \%$ found in this study [4].

Confirming the greater digestibility of crude glycerin, some authors reported that this co-product is a feed with a fast rate of ruminal fermentation, due to degradation of glycerol by microorganisms and the direct absorption occurring in the ruminal epithelium [22]. These statements are consistent if it is observed that $\mathrm{OM}$ apparent digestibility is greater in the CG25 and PMCG diets (81.26 and $77.76 \%$, respectively) compared to diets without crude glycerin inclusion (Control and PM20).

The greater apparent digestibility of crude protein can be explained by superior synchronism during fermentation of the proteins and carbohydrates in the diet. Protein sources of high degradability can have better utilization when associated with energy sources of high ruminal degradability [20]. The synchronization of ruminal availability of energy and nitrogen can allow higher efficiency in the microbial process of ammonia fixing in glutamate form, decreasing losses of nitrogen and energy.

Inclusion of peanut meal in the amount of $20 \%$ of DM (PM20) elevated the quantity of degradable protein compared to the Control diet, increasing the apparent digestibility of CP from $54.57 \%$ to $69.29 \%$ (Table 2). This increase was sufficient to equal the apparent digestibility of CP in the CG25 and PMCG diets, which although they have soybean meal in their composition (low degradable protein compared to peanut meal), contain the most highly digestible energy source, which allows ruminal microorganisms a better contribution of substrates, allowing high development and hence highest requirements for nitrogen, causing high apparent digestibility of CP.

Merlim [16] evaluated 10 and 20\% crude glycerin inclusion in feedlot lambs' diet and reported values for digestibility of CP (73.96\% and $75.44 \%$, respectively), both results higher than herein. However, crude glycerin inclusion did not elevate the digestibility of CP compared with the diet without co-product (75.29\%), differently from what occurred in this study.

In four diets assessed with equal levels of nitrogen (18\% of CP in DM), with roughage to concentrate ratio of 30:70 being forage Tifton milled as roughage, some authors did not report difference in digestibility of CP between treatments composed of soybean meal and peanut cake (76.19 and 76.52\%, respectively) [24], with these values being higher than for the PM20 diet in this study (69.26\%). Probably our results were lower because the roughage to concentrate herein was 40:60, and this difference in concentrate quantity may have caused lesser apparent digestibility of CP.

The increase in daily EEI can offset endogenous fat losses, resulting in ascension of apparent digestibility. The difference in apparent digestibility of EE of diets (Table 2) was related to nutrient intake, such that diets with higher nutrient intake (Control, PM20, and PMCG) had high apparent digestibility of EE $(88.21,89.91$, and $87.52 \%$, respectively) compared to the CG25 diet (80.82\%).

Similar to what occurred herein, when evaluated inclusion of peanut cake in replacement of soybean 
meal, was reported an increase in digestibility of EE, which was correlated positively with ingredient intake [25]. Authors found EE digestibility of 93.42 and $87.36 \%$ in diets with and without inclusion of $100 \%$ peanut cake, respectively.

The high daily EEI also resulted in high coefficients of digestibility of nutrients in the diet with growing levels of crude glycerin; this is because the percentage of fat acids in the co-product provide high fat availability in the small intestine for micelle formation and absorption [4]. Authors reported minimum and maximum values for EE digestibility in treatments with and without $10.84 \%$ glycerin in DM, of 78.98 and $55.85 \%$, respectively.

The greater apparent digestibility of NDF in diets with crude glycerin inclusion (CG25 and PMCG) can be explained by higher efficiency in energy-protein synchronism in the rumen, which generates higher apparent digestibility of $\mathrm{CP}$, resulting in greater concentration of protein substrates in the rumen, which could improve the cell wall degradation NDF fraction [29]. We know that the cellulolytic bacteria require ammonia as the main nitrogen source for growth. Therefore, the best energy-protein synchronism resulting in high efficiency in the microbial process of ammonia fixing, in glutamate form [20]. These results corroborate with the best apparent digestibility of NDF $(64.23 \%)$ in the diet with inclusion of crude glycerin in the amount of $25 \%$ of DM.

Equal results were reported by Rico et al. [23] who evaluated the effect of glycerol inclusion $(0,3,5$, and $8 \%$ of DM) in replacement for corn, in the diet of lactating cows. They found that increase in glycerol inclusion improved digestibility of NDF by $46.8 \%$ to $51.5 \%$, in diets without and with higher glycerol inclusion, respectively. These results were below those obtained by us for diets with inclusion of co-products: $57.23 \%$ (PM20), 64.23\% (CG25), and 63.29\% (PMCG).

Studying the digestibility of nutrients in cannulated cattle, fed with diets derived from biodiesel production as palm kernel and cakes of peanut and sunflower. Some authors did not report a difference between diets in digestibility of NDF (58.4\%) [9], a percentage similar to the result in this study for the inclusion of peanut meal $(57.23 \%)$ in relation to the Control diet (49.29\%). The peanut meal added to crude glycerin (PMCG) caused increased apparent digest- ibility of NDF (63.92\%) compared to the Control diet. This can be explained by the greater availability of ammonia in the rumen, which favoring development of cellulolytic bacteria.

The fact that crude glycerin is an energy ingredient that is better digested by rumen microorganisms, with extensive metabolism in the liver [11], makes it an ingredient with great digestibility. Confirming this finding, some studies reported that glycerol (the main component of glycerin), when ingested by a ruminant, is quickly fermented and within 4 to $6 \mathrm{~h}$ disappears almost entirely $[2,14]$.

The findings on the high digestibility of crude glycerin corroborate with results of this study for the apparent digestibility of DM, OM, NDF, and ADF, which was always higher in the diet with inclusion of this co-product.

In vitro cumulative gas production and volatile fatty acid quantification

In vitro cumulative gas production (Table 3 ) differed at the earliest time points $(2,4,6$, and 10 h), with the treatments with crude glycerin inclusion (CG25 and PMCG) resulting in higher gas production if compared to other treatments (Control and PM20). The data showed that treatment CG25 obtained higher initial gas production, followed by treatment PMCG which contained $12.5 \%$ crude glycerin. Probably these results were caused by the greater apparent digestibility of DM in treatments that included crude glycerin (Table 2). Should be highlighted that higher gas production after a given time of incubation demonstrated the fastest in vitro fermentation of the diet [31].

Different from results obtained in this study, evaluating the replacement levels $(25,50,75$ and 100\%) of soybean meal with by-products of the biodiesel industry (cotton, palm oil, castor, and jatropha) [1]. The authors reported that $100 \%$ inclusion of alternative ingredients in replacement of traditional ingredients caused lower in vitro cumulative gas production, with an average reduction of $23 \mathrm{~mL} / \mathrm{g}$ DM.

Our values for in vitro cumulative gas production and methane concentration were similar to those found by Castagnino et al. [6]. They evaluated glycerol inclusion in diets with and without vegetable oils (soybean and linseed) and reported an average volume of total gases of $50.62 \mathrm{~mL}, \mathrm{pH}$ of 6.7 to 6.9 , and $8.62 \%$ $\mathrm{g} / \mathrm{DM}$ incubated as average methane concentration. 
Our results of volatile fatty acid concentration are different from the decrease in molar proportion of acetic acid and increase of propionic acid described by several authors, with the inclusion of glycerin in the diet $[7,28]$. However, our results confirm the findings from another research, where were evaluated the volatile fatty acid profile in ruminal fluid of bovines fed with glycerin $(0,4,8$ and $12 \%$ in DM) [14]. They did not observe an effect of co-product inclusion on the molar proportion of acetic, propionic, and butyric acids, which averaged 53.2, 36.0, and $10.8 \mathrm{~mol} / 100$ mol, respectively.

A review about diets fed to sheep with coproducts resulting from extraction of vegetable oils (safflower, radish, sunflower, and crambe) described similar average values of acetic and propionic acid (51.23 and $22.70 \mathrm{mmol} / \mathrm{L}$ ) [5], to values found in this study (56.05 and $25.42 \mathrm{mmol}$ ), with total replacement of soybean meal by peanut meal. The equal results for acetic acid, herein, probably occurred due similar levels of neutral detergent fiber between the diets (Table 1). Once the acetic acid production is a result of fiber fermentation [5].

The values obtained herein from diets with crude glycerin inclusion (CG25 and PMCG) were close to those reported by Castagnino et al. [6], who added glycerol to diets with and without vegetable oils (soybean and linseed) and described an acetate:propionate ratio mean of 1.22. When assessing different residuals of extraction of vegetable oils in diets fed to sheep, the mean obtained for this ratio was 2.36 according this review [5]. This value was close to the values we obtained in Control and PM20 diets. Hence, we can observe that replacement of traditional ingredients by co-products did not alter the volatile fatty acid concentration and the acetate:propionate ratio.

\section{CONCLUSION}

The inclusion of peanut meal at 20\% DM and crude glycerin at $25 \%$ DM could successfully replace traditional diets of feedlot lambs such as soybean and corn, respectively, without impairing intake and rumi- nal parameters in vitro. Both co-products could reduce competition between animal and human food besides enhance the reutilization of low-quality material in the food industry that could pollute the environment due manufacturing excess.

\section{MANUFACTURERS}

${ }^{1}$ LECO Corporation. St. Joseph, MI, USA.

${ }^{2}$ Parr Instrument Company. Moline, IL, USA.

${ }^{3}$ Ankom Technology. Macedon, NY, USA.

${ }^{4}$ LANA/CENA-USP. Piracicaba, SP, Brazil.

${ }^{5}$ Shimadzu Corporation. Kyoto, Japan.

${ }^{6}$ Marconi Equipamentos Para Laboratórios Ltda. Piracicaba, SP, Brazil.

${ }^{7}$ Agilent Technologies. Colorado Springs, CO, USA.

${ }^{8}$ SAS Institute Inc. Cary, NC, USA.

Funding. This work was supported by the São Paulo Research Foundation (Fundação de Amparo à Pesquisa do Estado de São Paulo - FAPESP, grant \#2013/23495-5). E. P. Romanzini received scholarship from National Council of Technological and Scientific Development (CNPq, grant\#131978/2014-4). R. L. Valença and F. A. Merlim received scholarship from Brazilian Federal Coordination of Higher Education (Coordenação de Aperfeiçoamento de Pessoal de Nível Superior - CAPES). T. H. Borghi, P. A. Bernardes and P. S. Castagnino received scholarship from São Paulo Research Foundation (Fundação de Amparo à Pesquisa do Estado de São Paulo - FAPESP grants \#2012/25250-7, \#2013/09364-5 and \#2015/03918-4, respectively). N. Andrade received scholarship from National Council of Technological and Scientific Development (CNPq, grant \#142283/2014-2).

Acknowledgments. The authors thank the São Paulo State University by every all support during development of this study and to Program of Undergraduate of Animal Science of this University.

Ethical approval. The protocol used in this experiment was in accordance with National Council for Animal Experiments Control (CONCEA: Conselho Nacional de Controle de Experimentação Animal) guidelines and was approved by the Ethics Committee on Animal Use (CEUA: Comissão de Ética no Uso de Animais) from FCAV - Unesp/Jaboticabal Campus (protocol number 022014/13).

Declaration of interest. The authors wish to confirm that there are no conflicts of interest associated with this publication. The authors alone are responsible for the content and writing of this paper.

\section{REFERENCES}

1 Abdalla A.L., Silva Filho J.C., Godoi A.R., Carmo C.A. \& Eduardo J.L.P. 2008. Utilização de subprodutos da indústria de biodiesel na alimentação de ruminantes. Revista Brasileira de Zootecnia. 37: 260-268.

2 AbuGhazaleh A.A., Abo El-Nor S. \& Ibrahim S.A. 2011. The effect of replacing corn with glycerol on ruminal bacteria in continuous culture fermenters. Journal of Animal Physiology and Animal Nutrition. 95(3): 313-319. 
3 AOAC. 2006. Official Methods of Analysis. 18th edn. Association of Official Analytical Chemists: Washington, D.C., 1018 p.

4 Barros M.C.C., Marques J.A., Silva F.F., Silva R.R., Guimarães G.S., Silva L.L. \& Araújo F.L. 2015. Crude glycerin in diets for wethers in feedlot: intake, digestibility, performance, carcass and meat traits. Semina: Ciências Agrárias. 36(1): 453-466.

5 Brás P., Possenti R.A., Bueno M.S., Canova E.B. \& Schammas E.A. 2014. Nutritional evaluation of co-products from the extraction of plant oils in sheep diet. Boletim de Indústria Animal. 71: 160-175.

6 Castagnino P.S., Messana J.D., Fiorentini G., Jesus R.B., Vito E.S., Carvalho I.P.C. \& Berchielli T.T. 2015. Glycerol combined with oils did not limit biohydrogenation of unsaturated fatty acid but reduced methane production in vitro. Animal Feed Science and Technology. 201: 14-24.

7 Chanjula P., Pakdeechanuan P. \& Wattanasit S. 2014. Effects of dietary crude glycerin supplementation on nutrient digestibility, ruminal fermentation, blood metabolites, and nitrogen balance of goats. Asian-Australasian Journal of Animal Science. 27(3): 365-374.

8 Chanjula P., Pakdeechanuan P. \& Wattanasit S. 2015. Effects of feeding crude glycerin on feedlot performance and carcass characteristics in finishing goats. Small Ruminant Research. 123(1): 95-102.

9 Correia B.R., Oliveira R.L., Jaeger S.M.P.L., Bagaldo A.R., Carvalho G.G.P., Oliveira G.J.C., Lima F.H.S. \& Oliveira P.A. 2011. Intake, digestibility and ruminal $\mathrm{pH}$ of steers fed diets with pies coming from the production from biodiesel to replacement soybean meal. Arquivo Brasileiro de Medicina Veterinária e Zootecnia. 63(2): 356-363.

10 Donkin S.S. \& Doane P. 2007. Glycerol as a feed ingredient in dairy rations. In: Tri-State Dairy Nutrition Conference (Fort Wayne, USA). pp.97-103.

11 El-Nor S.A., AbuGhazaleh A.A., Potu R.B., Hastings D. \& Khattab M.S.A. 2010. Effects of differing levels of glycerol on rumen fermentation and bacteria. Animal Feed Science and Technology. 162(3): 99-105.

12 Goering H.K. \& Van Soest P.J. 1970. Forage fiber analyses (Apparatus, reagents, procedures and some applications). Washington, D.C.: Agricultural Research Service, 20p.

13 Lage J.F., Paulino P.V.R., Pereira L.G.R., Valadares Filho S.C., Oliveira A.S., Detmann E., Souza N.K.P. \& Lima J.C.M. 2010. Glicerina bruta na dieta de cordeiros terminados em confinamento. Pesquisa Agropecuária Brasileira. 45(9): 1012-1020.

14 Mach N., Bach A. \& Devant M. 2009. Effects of crude glycerin supplementation on performance and meat quality of Holstein bulls fed high-concentrate diets. Journal of Animal Science. 87(2): 632-638.

15 Mauricio R.M., Mould F.L., Dhanoa M.S., Owen E., Channa K.S. \& Theodorou M.K. 1999. A semi-automated in vitro gas production technique for ruminant feedstuff evaluation. Animal Feed Science and Technology. 79(4): 321-330.

16 Merlim F.A. 2015. Glicerina na alimentação de cordeiros Ile de France em terminação. 61f. Jaboticabal, SP. Master's Thesis (Master Degree in Animal Science) - Animal Science Postgraduate Program, São Paulo State University (Unesp).

17 Mertens D.R. 1992. Análise da fibra e sua utilização na avaliação de alimentos e formulação de rações. In: Simpósio Internacional de Ruminantes (Lavras, Brazil). p.188.

18 Monnerat J.P.I.S., Oliveira I.M., Paulino P.V.R., Mezzomo R., Silva L.H.P., Silva P.P. \& Ferreira J.P. 2013. Nutritional evaluation and performance of beef cattle fed with crude glycerin diets. In: Energy and protein metabolism and nutrition in sustainable animal production. Wageningen: Wageningen Academic Publishers, pp.97-98.

19 Mota D.A., Berchielli T.T., Canesin R.C., Rosa B.L., Ribeiro A.F. \& Brandt H.V. 2013. Nutrient intake, productive performance and body measurements of dairy heifers fed with different sources of protein. Acta Scientiarum. Animal Sciences. 35(3): 273-279.

20 Nocek J.E. \& Russell J.B. 1988. Protein and energy as an integrated system. Relationship of ruminal protein and carbohydrate availability to microbial synthesis and milk production. Journal of Dairy Science. 71(8): 2070-2107.

21 NRC - National Research Council. 2006. Nutrient Requirements of Small Ruminants: Sheep, Goats, Cervids, and New World Camelids. Washington, D.C.: The National Academies Press, 362p.

22 Rémond B., Souday E. \& Jouany J.P. 1993. In vitro and in vivo fermentation of glycerol by rumen microbes. Animal Feed Science and Technology. 41(2): 121-132.

23 Rico D.E., Chung Y.H., Martinez C.M., Cassidy T.W., Heyler K.S. \& Varga G.A. 2012. Effects of partially replacing dietary starch with dry glycerol in a lactating cow diet on ruminal fermentation during continuous culture. Journal of Dairy Science. 95(6): 3310-3317. 
24 Santos V.C., Ezequiel J.M.B., Morgado E.S., Fávaro V.R., D’Áurea A.P. \& Souza Junior S.C. 2014. Performance and digestibility of nutritional components of diets containing byproducts of oleaginous in lambs feeding. Semina: Ciências Agrárias. 35(3): 1577-1586.

25 Silva T.M., Medeiros A.N., Oliveira R.L., Gonzaga Neto S., Ribeiro M.D., Bagaldo A.R. \& Ribeiro O.L. 2015. Peanut cake as a substitute for soybean meal in the diet of goats. Journal of Animal Science. 93(6): 2998-3005.

26 Sniffen C.J., O’Connor J.D., Van Soest P.J., Fox D.G. \& Russell J.B. 1992. A net carbohydrate and protein system for evaluating cattle diets: II. Carbohydrate and protein availability. Journal of Animal Science. 70(11): 3562-3577.

27 Theodorou M.K., Williams B.A., Dhanoa M.S., McAllen A.B. \& France J. 1994. A simple gas production method using a pressure transducer to determine the fermentation kinetics of ruminant feeds. Animal Feed Science and Technology. 48: 185-197.

28 van Cleef E.H.C.B., Almeida M.T.C., Perez H.L., van Cleef F.O.S., Silva D.A.V. \& Ezequiel J.M.B. 2015. Crude glycerin changes ruminal parameters, in vitro greenhouse gas profile, and bacterial fractions of beef cattle. Livestock Science. 178: 158-164.

29 Van Soest P.J. 1994. Nutritional Ecology of the Ruminant. Ithaca: Cornell University Press, 476p.

30 Van Soest P.J., Robertson J.B. \& Lewis B.A. 1991. Methods for dietary fiber, neutral detergent fiber, and nonstarch polysaccharides in relation to animal nutrition. Journal of Dairy Science. 74(10): 3583-3597.

31 Wang M., Sun X.Z., Tang S.X., Tan Z.L. \& Pacheco D. 2013. Deriving fractional rate of degradation of logisticexponential (LE) model to evaluate early "in vitro" fermentation. Animal. 7(6): 920-929. 